\title{
TRUST AND ORGANISATIONAL CHANGE: AN EXPERIENCE FROM MANUFACTURING
}

\author{
AMANDA HAY \\ Department of Human Resource Management \\ Nottingham Business School \\ Nottingham Trent University \\ ABSTRACT
}

The introduction of new working practices in manufacturing organisations often highlight increased interdependencies and subsequently a heightened need for trust. The paper presents a study which monitors trust in an organisation that has introduced two such practices, namely team working and Just-In-Time. The study examines trust at a variety of levels at the organisation, over 21 months. It follows the progression of the new working practices, employing a combination of quantitative and qualitative methods. The results show that significant changes in trust occur over time. Further, benefits and consequences of trust to the new working practices are detailed.

\section{OPSOMMING}

Die inwerkingstelling van nuwe werkspraktyke in vervaardigingsorganisasies beklemtoon dikwels ' $\mathrm{n}$ verhoogde interafhanklikheid en gevolglik 'n verskerpte behoefte aan vertroue. Hierdie artikel bespreek die monitering van vertroue in ' $n$ organisasie wat twee projekte gëmplementeer het, naamlik spanwerk en net-betydse werk. Die studie ondersoek vertroue oor ' $n$ periode van 21 maande, in ' $n$ verskeidenheid van vlakke in die organisasie. Dit volg die ontwikkeling van nuwe werkspraktyke deur 'n kombinasie van kwantitatiewe en kwalitatiewe metodes. Die resultate toon dat betekenisvolle verskille in vertroue oor tyd plaasvind. Die voordele en gevolge van die nuwe werkspraktyke op vertroue word ook bespreek.

Researchers are increasingly recognising that context is critical to our understanding of trust in organisations (Blomqvist, 1997, Sitkin, Rousseau, Burt \& Camerer, 1998). Trust is presented in the literature as a multi-faceted, dynamic and complicated construct (Butler \& Cantrell, 1984, Mechanic, 1996), yet existing studies of trust neglect this complexity by failing to consider or concern themselves with context. Many existing studies of trust centre on hypothetical or artificial situations and/or make use of undergraduate populations (Butler, 1999; Dirks, 1999; Porter \& Lilly, 1996; Zand, 1972). Such studies raise concerns about generalisability to real world settings. Further, studies of trust in real world settings are rare. Indeed, Lane (2000, p. 2) notes that 'the consequences of trust for organisational performance have so far not received systematic study'. Given this, the study of trust in real organisations is thus required.

Real world organisations are becoming increasingly complex and rapidly changing places. Many argue that under such conditions trust is crucial to an organisation's success (Dunford, 1999; Martins, 1999). Indeed, Peters (1994, p. 145) refers to trust as the 'oft ignored glue that holds the new fangled virtual organisation together'. It is therefore difficult to see how trust can be adequately understood taken out of context.

How one defines trust is also likely to vary with context. Despite the increasing importance of trust there is still a lack of clarity as to what trust is. Definitions which centre on expectation and reliance (Rotter, 1967), risk (Coleman, 1990) and dependence (Zand, 1972) are just a few of the definitions found. Further, others highlight the multi-faceted nature of trust suggesting key components such as integrity, competence and openness (Butler \& Cantrell, 1984). It may be that when studying the concept situational variables prevail to emphasise different components of the concept. Indeed, Blomqvist (1997) argues that the weak conceptualisation of trust is partly due to the fact that trust is always situation specific, in other words context does matter.

The definition of trust adopted for the purpose of this study is that of Cook and Wall (1980, p. 39) who define trust as the extent to which one is willing to ascribe good intentions to and have confidence in the words and actions of other people'. Their definition thus has two dimensions: faith in the

Requests for copies should be addressed to: A Hay, Department of Human Resource Mangement, Nottingham Business School, Nottingham. E-mail: A.J.Hay@derby.ac.uk trustworthy actions of others and confidence in the ability of others. This definition was developed in a manufacturing context and it is a manufacturing organisation, which provides the setting for this study.

\section{The rise of interdependence}

In manufacturing the introduction of new work practices are linked with increased interdependency between organisational members (Dean \& Snell, 1991). It is suggested that this is strongly associated with the noted increased importance of trust since people must depend on others in various ways to accomplish their personal and organisational goals. Such circumstances heighten the need for trust (Mayer, Davis \& Schoorman, 1995). Two practices which are frequently used in manufacturing which heighten inter-dependencies and thus a need for trust are teamworking and Just-In-Time.

\section{Teamworking}

The practice of teamworking is widely used in UK manufacturing, with some $70 \%$ of respondents in the survey by Waterson, Clegg, Bolden, Pepper, Warr and Wall (1997) reporting its use. The introduction of teamworking is associated with changes in the way workers interact with each other: a move towards collective effort, joint goal sharing and thus increased interdependency are found (Safizadeh, 1991). Not surprisingly, trust is therefore viewed as a key characteristic of high performing teams (Katzenbach \& Smith, 1993). It is suggested that trust is important to teamworking as it promotes the co-operation necessary for successful teamwork (Jones \& George, 1998).

It is further suggested that trust may not only be required between individual members within teams, but may also be important to relations between teams. West (1994) argues that teams rarely operate in isolation and will develop either a cooperative or competitive orientation towards other teams in the organisation. Thus it may be argued that the presence of trust between teams may promote a co-operative orientation.

At a managerial level, trust is also seen as critical to the success of teamworking since in practice, teams are often required to function with a degree of autonomy. Therefore, management must allow workers the freedom to perform their jobs without close supervision and thus a high trust management style is required (Procter \& Mueller, 2000). Despite the suggested importance of trust to the practice of teamworking, there is a paucity of empirical study. 


\section{Just-In-Time}

Just-In-Time (JIT) is another widely adopted practice and is essentially a system which aims to reduce work in progress, producing only the amount specified by the customer, to ensure that goods are produced at a reduced cost in minimum time (Schonberger, 1986). The simplicity of the system is appealing, although attempts to implement JIT have varying success rates. Peters $(1987$, p. 118) notes that 'most JIT experiments have failed to reach their potential, not because of inadequate computerisation, but because of a fundamental failure on the part of the participants to understand the new attitudes of trust, co-operation and mutual investment'. A key reason why trust and co-operation are so important to JIT is because the low levels of work in progress and the removal of stock buffers heighten interdependencies within the system (Oliver \& Wilkinson, 1992). In other words, each unit in the system depends upon other units in the system for the smooth throughput of work. A JIT system is therefore an example of where great benefit can be achieved through co-operative relations between teams. As with teamworking, there are few empirical studies, which have examined trust in the context of a JIT environment.

\section{Trust in a variety of organisational relationships}

The above two practices highlight interdependencies throughout the organisation and thus a need to study trust at a number of different levels. However, previous studies tend to focus almost exclusively on managerial trust (e.g. Clark \& Payne, 1997; Deluga, 1995; Thomas \& Schindler, 1993). Whilst managerial trust is of obvious importance, the need to study trust in other relationships, for example the relationships between team members is becoming increasingly important. Indeed, Smith, Carroll and Ashford, (1995, p. 15) suggest that 'the study of trust and its impact on co-operative relationships at all levels may be a particularly fruitful area of future research'.

\section{The dynamic nature of trust}

Finally, an important contextual factor for today's organisations is continual change. In particular, practices such as JIT maintain a constant state of flux in the organisation. Therefore, it would seem important to study trust over time. Further, trust itself is dynamic and fragile and is easily challenged by a disconfirming act or changing social situation (Mechanic, 1996). Therefore, trust is likely to be tested in organisations where change prevails. Despite this, longitudinal studies of trust in organisations are rare (Zaheer, Macevily \& Perrone, 1998) and thus neglect the dynamic nature of trust.

\section{The present study}

The present study examines trust in a real world manufacturing organisation where teamworking and JIT have replaced an individual piecework system. The study aims to explore trust in a number of relationships in the organisation and further to monitor changes in these relationships over time. The research questions of the study are therefore as follows:

i) What changes occur over time in a) team trust?

b) inter team trust?

c) management trust?

ii) What are the benefits of trust to the new working practices?

ii) What are the consequences of mistrust to the new working practices?

\section{METHOD}

\section{Design}

The study employed a longitudinal design given the noted dynamic nature of trust and focused on a single case study organisation. The case study organisation was located in the UK, employed approximately 100 workers and was involved in industrial wirework. The study used a combination of quantitative and qualitative methods, namely a survey and focus groups. This moves away from the traditional study of trust. Although a complex and dynamic construct, trust tends to be studied almost exclusively by quantitative methods. Similarly, Lewis and Weigert (1985) warned that current methodologies for measuring trust had reductionist consequences. It is argued that over 15 years later, this is still the case. Whilst important information can be revealed by quantitative measure, the richness of data that can be obtained by qualitative study when attempting to understand trust should not be ignored. Further, it is suggested that qualitative study is important in providing contextual detail, which is required to enhance our understanding of trust.

\section{Sample}

The survey aimed to include all members of the case study organisation given the relatively small size of the company. Two surveys were conducted (T1 and T2), at T1 97 employees completed the survey and 83 at T2. Therefore this represents a response rate of $93 \%$ at $\mathrm{T} 1$ and $80 \%$ at $\mathrm{T} 2$. For the purposes of the analysis only those respondents who completed the survey at both $\mathrm{T} 1$ and $\mathrm{T} 2$ were included $(\mathrm{N}=76)$.

Four focus groups were employed, each focus group representing a work team in the organisation. Focus groups comprised between 3-9 members $(\mathrm{N}=18)$. In selecting the focus groups a theoretical sampling model was used. Mays and Pope (1995) suggest this is where participants are selected to reflect a range of the total study population or to test particular hypotheses. Here the rationale behind the sample selection was two fold. Firstly, the four selected groups reflected a range of work teams, e.g. product groups, size of team. Secondly, the sample included two groups that had scored relatively highly on measures of trust in the T1 survey and two that had scored relatively lower.

\section{Measures}

The measure of workplace trust developed by Cook and Wall (1980) was adapted for use in this study. Trust was measured in three relationships, namely team, inter team and management, sample items from the three measures are shown below.

Team 'If I got into difficulties at work, I know the other members of my team would try and help me out'

Inter team 'If I got into difficulties at work, I know the other teams would try and help me out'

Management 'Management is sincere in its attempts to meet the employees' point of view'

\section{Procedure}

The survey was conducted at two time intervals (T1 and T2) with a gap of 11 months. The survey was conducted by the researcher at the case study organisation during work hours. The focus groups were conducted 5 months after the T1 survey, again at the case study organisation in an environment familiar to the participants. Focus groups lasted between 4075 minutes.

The focus groups aimed to explore the survey findings in greater depth and to examine possible benefits of trust and consequences of mistrust at the case study organisation. Confidentiality of responses was stressed at all stages of the research process.

\section{RESULTS}

Table 1 shows that each of the measures demonstrated an acceptable level of reliability at T1 and T2, in accordance with the criteria of Nunally and Bernstein (1993), which suggests that co-efficients of 0,70 and above demonstrate adequate reliability. The variables also show significant inter correlation. 
TABLE 1

Alphas, means, STANDARD DeViations AND

CORRELATIONS AMONG VARIANTS

\begin{tabular}{|c|c|c|c|c|c|c|c|c|}
\hline & alpha & mean & sd & 1 & 2 & 3 & 4 & 5 \\
\hline 1. Team trust $\mathrm{T} 1$ & 0,92 & 3,90 & 0,63 & - & & & & \\
\hline 2. Inter team trust $\mathrm{T} 1$ & 0,84 & 3,32 & 0,68 & $0,37 * *$ & - & & & \\
\hline 3. Management trust $\mathrm{T} 1$ & 0,89 & 3,27 & 0,63 & $0,52^{* *}$ & $0,63^{* *}$ & - & & \\
\hline 4. Team trust $\mathrm{T} 2$ & 0,94 & 3,92 & 0,66 & $0,35^{* *}$ & $0,25^{*}$ & $0,26^{*}$ & - & \\
\hline 5. Inter team trust $\mathrm{T} 2$ & 0,79 & 3,13 & 0,71 & $0,25^{*}$ & $0,62^{* *}$ & $0,40^{* *}$ & $0,47^{* *}$ & - \\
\hline 6. Management Trust $\mathrm{T} 2$ & 0,88 & 2,92 & 0,67 & 0,20 & 0,23 & $0,43^{* *}$ & $0,27^{*}$ & 0,57 * * \\
\hline
\end{tabular}

TABLE 2

Change OVer TIME IN TRUST

$\begin{array}{lcccc}\text { Variable } & \text { T1 [mean] } & \text { T2 [mean] } & \mathrm{F} & \mathrm{P} \\ \text { 1. Team trust } & 3,90 & 3,92 & 0,47 & \text { ns } \\ \text { 2. Inter team trust } & 3,32 & 3,13 & 7,72 & \text { * * } \\ \text { 3. Management trust } & 3,27 & 2,92 & 17,74 & \text { * * } \\ { }^{* *} \mathrm{p}<0,01 & & & & \end{array}$

FiguRE 1: COMPARISON OF CHANGE OVER TIME IN TEAM, INTER TEAM AND MANAGEMENT TRUST

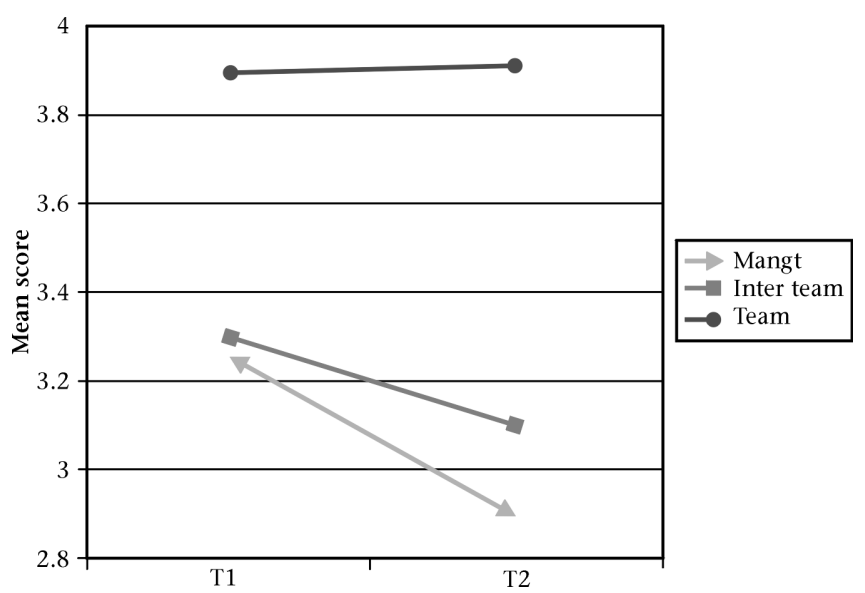

Team trust

Figure 1 clearly shows that team trust was higher than both inter team trust and trust in management. It can be seen that team trust shows little change over time $(\mathrm{F}=0,47$, $\mathrm{df}=1,72, \mathrm{p}>0,05)$. The focus group findings were supportive of a high level of team trust and suggested benefits that might be found, for example ' $I$ trust him [team member] his judgement and what have you. You've got to trust team members or else like, it's not going to work, it's [team] not worth having' suggesting a high level of team trust and further proposing that trust is fundamental to the functioning of the team.

Further, it would seem that the presence of team trust facilitates dependency between team members: 'You trust that that person's gonna be there to help you get that job out. I mean I'm the team leader and I can cos I go away a lot and I know these two would get the work out. No problem at all. I feel more dependent on these two cos like I'm never there' and encourages loyalty to the team: ' $I$ 'd cover for any of these I would. If I know I could help her to get away with it, without causing anyone bother and anyone finding out about it, I'd try and help out'.
Finally, the focus groups revealed an additional benefit of team trust: 'I would tell [other team member] more things than other people. Yeah you're more open to the people you see everyday, trust 'em more', suggesting that trust can promote more open communication between team members.

Inter team trust

Table 2 and figure 1 reveal that trust between teams was lower than trust within teams and further suggest that trust between teams decreases significantly over time $(\mathrm{F}=7,27, \mathrm{df}=1,74, \mathrm{p}<$ $0,01)$. The focus group findings likewise suggest a low level of trust between teams and highlight a number of subsequent consequences.

The following clearly supports the low level of inter team trust found by the survey: 'I feel that the teams are competing against each other and not for each other. There is a lot of mistrust between employees on the factory floor which leads to a lot of arguments and this causes more tension. If people learnt to work for one another the atmosphere would be a lot better', and suggests that the mistrust present between the work teams results in arguments and tension and generally a bad working atmosphere on the shopfloor.

Such an atmosphere is further suggested by the following: 'an example of mistrust is that every tool box has got a lock on it. Every single one and there can't be much trust there. You can't trust other teams not to take your tools. Not one single one has got an open toolbox'. This suggests that the lack of trust present between the work teams also results in a reluctance to share equipment, which may lead to decreased efficiency.

Finally, with respect to inter team trust, some responses suggested that the low trust is comparable with the mistrust of the former piece rate system: 'I don't know if I trust other teams, there is some people like you can say 'oh yeah go on that job' you know they're going to do the job for you. There's some people are going to go on it and they're not going to achieve what you want. You know what I mean?... They say they can't make the job, it's like under piece rate, the old levels. Some of them don't even try you know. You don't have to go for it - there's no carrot'. This suggests that individuals tend to look out for their own team's interests, ensuring that their own targets are met, and appear less interested in helping other teams out when needed. This is likely to result in overall underachievement of JIT targets.

Trust in management

From table 2 and figure 1 it can be seen that trust in management is lower than both team trust and trust between teams. Trust in management also decreases significantly over time $(\mathrm{F}=17,74, \mathrm{df}=1,70, \mathrm{p}<0,01)$. 
The focus group findings strongly supported a low level of trust between management and workers, for example 'management treat people like dirt...they can't be trusted at all. Nobody on the shopfloor, including supervisors have any respect for the works manager. Me personally, I am here to sponge off this company as much as I can until I find a new job. I would willingly mess up our schedule to give my team members more overtime, even if not needed' suggesting a strong 'them and us' divide and, furthermore, that mistrust of management can result in decreased organisational commitment and deliberate attempts to sabotage JIT schedules to gain advantage.

Other respondents gave clues as to how this mistrust was built up: 'There's a lot of things that are done behind closed doors. They're not straight about a lot of things. Like these two supervisors, nobody knew about it on the shopfloor until it was done. It's got to be done in the open, it should've been advertised, everybody should've had a crack at it. Why do it-just pick two and then come and tell you that you've got two new supervisors? Why weren't everybody involved in it? That's why you mistrust management', suggesting that management are closed and secretive, which results in mistrust and subsequently feelings of lack of involvement in decisions and injustice.

Finally, workers suggested that the mistrust present between workers and management was mutual: 'I think they think we're a bit thick and stupid on the shopfloor. We can say 'we can get...', like the other day they want a job doing and we'll say 'we'll get it out' and they keep coming up to you, 'Will you get it out? Will you get it out?' 'Yeah we'll get it out'. So they don't like one hundred percent trust you to get this job out', suggesting that management also mistrust workers and that this is associated with a constant checking on the workers' actions.

\section{DISCUSSION}

\section{Changes in trust over time}

The findings suggest that team trust showed little change over time, which points to the robustness of team trust. In contrast, significant decreases were found in both trust between teams and trust in management. The changes found in trust over time thus support Mechanic (1996), who suggests that trust is dynamic and fragile. Arguably, inter team trust and managerial trust display greater fragility, seeming more vulnerable to changes found in the organisation. Team trust, on the other hand, displayed greater resistance to organisational events over the period of the study.

It may be argued that trust within smaller groups may arise more easily than trust within larger groups. When the group becomes larger, it may be that trust becomes more complex and sensitive to changes in the organisation, and thus may need to be consciously monitored. Indeed, Scott, Aiken, Mechanic and Moravcsik (1995) propose that maintaining trust requires organisational strategies as well as good intentions. It could be argued that the case is heightened for trust in larger groups, in this case between teams and between management and workers.

\section{Benefits of trust}

The study suggested that the presence of trust can bring a number of benefits. Here it was found that trust between team members was fundamental to the functioning of the team and saliently promoted co-operative behaviour. This provides empirical support for Jones and George (1998) and Mayer et al (1995), who proposed that trust is important to the cooperation necessary for successful teamworking. The findings further suggested that trust between team members was associated with more open communication. Open communication is considered important to teamworking (Payne, 1990) and is also required by practices such as JIT, as used here, to ensure that problems are identified and solved as quickly as possible (Helms, 1990). Thus overall, the presence of trust in teams at this organisation would seem to have facilitated the change to teamworking.

\section{Consequences of mistrust}

Generally, the study suggested that trust is more visible by its absence and that the subsequent mistrust resulted in a number of consequences for the new working practices. Mistrust was present between teams and resulted in arguments, tension and a reluctance to share resources. Such consequences can be seen as detrimental to the JIT system since they would appear almost contrary to the requirements of JIT: namely that the necessary co-operation be replaced by conflict. The mistrust found between teams would appears to fuel divisions in the organisation and thus to promote defensive relationships. This could be said to reflect a piece rate environment which tends to promote a culture of parochialism, distrust, secrecy and finger pointing (Schonberger, 1986). The mistrust and associated lack of co-operation between teams thus highlights problems for JIT and further suggests the difficulties in replacing a system which is characterised by low trust with one that is characterised by high trust.

The findings also demonstrated that workers lacked trust in management and also that this situation deteriorated over time. The mistrust resulted in a number of negative consequences for both teamworking and JIT. Mistrust of management was found to result in deliberate attempts to gain advantage over management by tampering with JIT production schedules. This highlights the vulnerability of the newly implemented JIT system, which is shown to rely on the trustworthy behaviour of workers. Further, this finding supports the work of Rusbult, Farrell, Rogers and Mainous, (1988), who similarly found that employees who felt betrayed by management resorted to destructive behaviours such as neglect and, in extreme cases, sabotage. The study also found that mistrust of management lead to decreased organisational commitment, which is likely to detract from the effort that is applied to ensuring the success of the new practices.

Destructive organisational behaviours such as decreased commitment and sabotage, can be seen as defensive behaviours which go hand in hand with mistrust. In support of this, Kramer and Tyler (1996) argue that as trust declines people increasingly insist on costly sanctioning mechanisms to defend their own interests. Further, once mistrust sets in it is difficult to break the cycle of mistrust which involves, for example, negative assumptions and self-protective behaviour (Ryan \& Oestriech, 1998). The decline in trust found here would seem to suggest the presence of such a cycle. Moreover, workers felt that not only did they mistrust management, but management mistrusted them.

A result of the perceived mistrust displayed towards workers was a lack of autonomy given to perform the job. Workers felt that management constantly monitored their progress, which Frey (1993), suggests lowers trust. This position is of particular concern here as Procter and Mueller (2000) argue that teamworking requires a high trust management style allowing workers the necessary autonomy to carry out their jobs. It may be that this is especially challenging here, as the former piece rate system is strongly associated with a low trust management style. This raises general concerns for organisations that introduce new working practices which are centred around trust, such as teamworking and JIT, to replace old practices centred around mistrust, such as piece rate.

\section{Implications}

The study has a number of implications for both research and practice. It is argued that future research may wish to employ both quantitative and qualitative methods to provide a more 
rounded understanding of trust. Furthermore, given the changes found over time in trust, there is a clear need for longitudinal study of trust. Given the differences found in trust in different relationships, there is a strong argument for the study of trust at a number of different levels.

In practice, trust is important to new working practices such as teamworking and JIT. Trust can facilitate the co-operation necessary to both practices. Mistrust, however, can have serious consequences for such practices, resulting in conflict and divisions in the organisation. Trust is dynamic and changes as the organisation changes and thus needs to be consciously monitored.

\section{REFERENCES}

Blomqvist, K. (1997). The many faces of trust. Scandinavian Journal of Management, 13 (3), 271- 286.

Butler, J.K. (1999). Trust expectations and information sharing, climate of trust and negotiation effectiveness and efficiency. Group and Organisational Management, 24 (2), 217-238.

Butler, J.K. \& Cantrell, R.S. (1984). A behavioural decision theory to modelling dyadic trust in supervisors and subordinates. Psychological Reports, 55, 9-28.

Clark, M.C. \& Payne, R.L. (1997). The nature and structure of workers' trust in management. Journal of Organisational Behaviour, 18, 205-224.

Coleman, J.S. (1990). Foundations of social theory. Cambridge, MA: Harvard University Press.

Cook, J. \& Wall, T.D. (1980). New work attitude measures of trust, organisational commitment and personal need non fulfilment. Journal of Occupational Psychology, 53, 39-52.

Dean, J.W. \& Snell, S.A. (1991). Integrated manufacturing and job design: Moderating effects of organisational inertia. Academy of Management Journal, 34 (4), 776-804.

Deluga, R.J. (1995). The relation between trust in the supervisor and subordinate organisational citizenship behaviour. Military Psychology, 7 (1), 1-16.

Dirks, K.T. (1999). The effects of interpersonal trust on work group performance. Journal of Applied Psychology, 84 (3), 445455 .

Dunford, R. (1999). If you want loyalty get a dog! Loyalty, trust and the new employment contract. In S.R. Clegg, E. IbarraColado \& R.Bueno (Eds.). Global management: Universal theories and local realities. London: Sage.

Frey, B.S. (1993). Does monitoring increase work effort? The rivalry between trust and loyalty. Economic Enquiry, 31, 663-670.

Helms, M.M. (1990). Communication the key to JIT success. Production and Inventory Management Journal, 31, 18-21.

Jones, G.R. \& George, J.M. (1998). The experience and evolution of trust: Implications for co-operation and teamwork. Academy of Management Review, 23 (3), 393-404.

Katzenbach, J.R. \& Smith, D.K. (1993). The wisdom of teams. Boston, MA: Harvard Business School.

Kramer, R.M. \& Tyler, T.R. (1996). Trust in organisations: Frontiers of theory and research. London: Sage.

Lane, C. (2000). Introduction: theories and issues in the study of trust. In C. Lane \& R. Bachmann (Eds.). Trust within and between organisations: Conceptual issues and empirical applications. Oxford: Oxford University Press.

Lewis, D.J. \& Weigert, A. (1985). Trust as a social reality. Social Forces, 63, 967-985.
Martins, N. (1999, July). Managing employee trust during transformation. Paper presented at VIth European Congress of Psychology, Rome.

Mayer, R.C., Davis, J.H. \& Schoorman, F.D. (1995). An integrative model of organisational trust. Academy of Management Review, 20 (3), 709-734.

Mechanic, D. (1996). Changing medical organisation and the erosion of trust. The Milbank Quarterly, 74 (2), 171-189.

Nunnally, J. \& Bernstein, I. (1993). Psychometric theory (3rd ed.). New York: McGraw Hill.

Oliver, N. \& Wilkinson, B. (1992). The Japanisation of British industry: New developments in the 1990s. Oxford: Blackwell Business.

Payne, R. (1990). The effectiveness of research teams: a review. In M.A.West \& J.L.Farr (Eds.). Innovation and creativity at work. Psychological and organisational strategies. Chichester: John Wiley.

Peters, T. (1987). Thriving on chaos. New York: Alfred Knopf.

Peters, T. (1994). The Tom Peters' Seminar. London: Macmillan.

Porter, T.W. \& Lilly, B.S. (1996). The effects of conflict, trust and task commitment on project team performance. The International Journal of Conflict Management, 7 (4), 361-376.

Procter, S. \& Mueller, F. (2000). Teamworking. London: Macmillan Business

Rotter, J. (1967). A new scale for the measurement of interpersonal trust. Journal of Personality, 35, 651-665.

Rusbult, C.E., Farrell, D., Rogers, G. \& Mainous, A.G. (1988). Impact of exchange variables on exit, loyalty and neglect: An integrative model of responses to declining job satisfaction. The Academy of Management Journal, 31, 599-627.

Ryan, K.D. \& Oestriech, D.K. (1998). Driving fear out of the workplace: How to overcome the invisible barriers to quality, productivity and innovation. San Francisco: Jossey Bass Publications

Safizadeh, M.H. (1991). The case of workgroups in manufacturing operations. California Management Review, 35 (4), 61-82.

Schonberger, R.J. (1986). World class manufacturing: The lessons of simplicity applied. New York: Free Press.

Scott, R.A., Aiken, L.H., Mechanic, D. \& Moravcsik (1995). Organisational aspects of caring. Milbank Quarterly, 73, 77-95.

Sitkin, S.B., Rousseau, D.M., Burt, R.S. \& Camerer, C. (1998). Not so different after all: a cross discipline view of trust. Academy of Management Review, 23 (3), 393-404.

Smith, K.G., Carroll, S.J. \& Ashford, S.J. (1995). Intra and inter organisational co-operation: Toward a research agenda. Academy of Management Journal, 38, 7-23.

Thomas, C.C. \& Schindler, P.L. (1993). The structure of interpersonal trust in the workplace. Psychological Reports, 73, 563-573.

Waterson, P., Clegg, C.W., Bolden, R., Pepper, K., Warr, P.B. \& Wall, T.D. (1997). The use and effectiveness of modern manufacturing practice in the United Kingdom. Report to the ESRC: Institute of Work Psychology, Sheffield.

West, M.A. (1994) Effective Teamwork. Leicester: British Psychological Society.

Zaheer, A., McEvily, B. \& Perrone, V. (1998). Does trust matter? Exploring the effects of inter organisational and interpersonal trust on performance. Organisation Science, 9 (2), 141-159.

Zand, D.E. (1972). Trust and managerial problem solving. Administrative Science Quarterly, 17, 229-240. 


\section{(QP}

\section{Centre for Industrial \& Organisational Psychology}

\section{We offer the following:}

\begin{tabular}{|l|l|}
\hline PRO & \\
GR & \\
AM & anced Organisational Development \\
MES & nt Service Excellence \\
& han Resources Assessment \\
& istrial and Organisational Psychology \\
& \\
\hline
\end{tabular}

\begin{tabular}{|c|l|}
\hline COURS & Business Psychology and Human Behaviour \\
EN & Career Management \\
SHORT & Group Process Consultation \\
COURS & Learning Provision Quality Assurance \\
ES & Occupational Health and Safety Act of 1993 \\
& Occupational Ergonomics \\
& Skills Development Facilitation \\
& Victim Empowerment and Support \\
& Workforce Diversity \\
\hline
\end{tabular}

\begin{tabular}{|c|l|}
\hline WORK & \\
SHOPS & Effective Presentation Skills \\
AND & Self Management and Related Skills \\
AUDIT & Skills Development Facilitation \\
S & Organisational Trust Audit \\
& \\
&
\end{tabular}

Enquiries may be directed to:

Carmien Snyman

Tel: (012) 4298548

E-mail: snymacn@unisa.ac.za
Aretha Frost

Tel: (012) 4298003

E-mail: frosta@unisa.ac.za

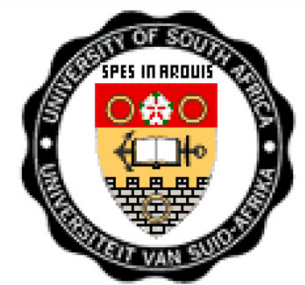

Fax: (012) 4298578 